\title{
APLIKASI PEMETAAN BERBASIS WEBSITE UNTUK PUSAT KESEHATAN MASYARAKAT DI WILAYAH KABUPATEN MALANG
}

\author{
Yosep Agus Pranoto ${ }^{1}$, Moh Miftakhur Rokhman ${ }^{2}$, Suryo Adi Wibowo ${ }^{3}$ \\ 1,2,3) Teknik Informatika, Institut Teknologi Nasional Malang \\ yoaitn@gmail.com
}

\begin{abstract}
ABSTRAK
Dewasa ini masyarakat di Indonesia di dukung dengan pemerintah meningkatkan pelayanan dalam bidang kesehatan diantarranya dengan mmbentuk suatu badan yang berfungsi untuk mendukung ketahanan kesehatan nasional yang disebut dengan BPJS (badan penyelenggara jaminan sosial).sehubungan dengan hal tersebut dengan banyaknya animo masyarakat dalam menggunakan jamina sosisal dalam bidang kesehatan membutuhkan tempat dan layanan fasilitas kesehatan yang prima.Penggunaan media website sebagai media dipilih Karena maraknya pengguna internet aktif di Indonesia yang mendudukkan Indonesia di peringkat ke-6 terbesar di dunia dalam hal jumlah pengguna internet pada tahun 2017 sehingga dengan beragamnya system operasi yang diadopsi oleh vendor perangkat menjadikan media website menjadi sebuah media yang bersifat multi-platform yang tidak mengenal adanya perbedaan system operasi yang diadopsi oleg berbagai macam vendor perangkat mobile. Pada pengujian fungsional, fungsi $100 \%$ sudah sesuai dengan kebutuhan aplikasi baik pada browser desktop maupun mobile serta dari $75 \%$ pengguna menilai aplikasi ini bermanfaat.Dari hasil pengujian efisiensi waktu terlihat bahwa untuk penggunaan aplikasi desktop browser memiliki efisiensi waktu yang dapat dihemat rata-rata sebesar 87,7\% dan $75 \%$ untuk mobile browser. Perbedaan hasil pengujian efisiensi waktu dipengaruhi karena dengan menggunakan media mobile yang menggunakan ukuran display jauh lebih kecil turut mempengaruhi performa usability.
\end{abstract}

Keyword : Sig,Web-GIS,Puskesmas,Kota Malang

\section{PENDAHULUAN}

Pemerataan dan peningkatan mutu pelayanan merupakan isu yang tidak terlepas dari peningkatan jangkauan dan perluasan pelayanan kesehatan, dalam hal ini pembangunan kesehatan di daerahdaerah pinggiran kota besar juga merupakan salah satu dalam isu tersebut dimana salah satu lokasi yang terkait dengan isu tersebut yaitu di kota Malang. Penyelenggaraan upaya pelayanan kesehatan di daerah seringkali mengalami hambatan karena kurangnya sarana transportasi, komunikasi, serta minimnya informasi letak geografis fasilitas kesehatan yang dituju,sehingga permasalahan tersebut menjadi isu penting yang terjadi di masyrakat sehingga menjadikan kurang popuernya akses fasilitas kesehatan tingkat I yang ada sebagai sarana pelayanan kesehatan terdepan terutama di wilayah kota malang.

Dengan boomingnya teknologi internet murah dan cepat di kota-kota besar dalam beberapa tahun terakhir menjadikan pengembangan berbagai aplikasi atau software berbasis website semakin berkembang. Salah satu dampak dari hal tersebut adalah populernya produk perangkat lunakdalam bentuk Sistem Informasi Geografi (SIG). Dimana SIG adalah sebuah sistem untuk pengelolaan, penyimpanan, pemrosesan, analisis dan penayangan (display) data yang terkait dengan permukaan bumi. Berbicara perkembangan SIG saat ini kiranya tidak lengkap tanpa menyinggung perkembangan teknologi informasi (TI). Saat ini teknologi informasi sudah sangat maju, telah ada internet yang menjembatani komunikasi tanpa batas, perkembangan webserver, harddisk dalam kapasitas terrabyte dan sebagainya.

Isu permasalahan dalam lingkup minimnya informasi letak geografis yang menyebabkan kurangnya akses pengetahuan terhadap letak fasilitas kesehatan yang paling dekat dengan lingkungan pengguna di kota malang dapat memanfatkan teknologi dari Sistem Informasi Geografi (SIG).diharapkan dari penelitian ini peneliti dapat membuat sebuah sistem informasi geografis berbasis website yang dapat memudahkan masyarakat mencari lokasi fasilitas kesehatan yang diinginkan di wilayah kota malang menggunakan sistem Informasi Geografi (SIG) berbasis web. Penggunaan media website dipilih Karena maraknya pengguna internet aktif di Indonesia yang mendudukkan Indonesia di peringkat ke-6 terbesar di dunia dalam hal jumlah pengguna internet dimana pada tahun 2017 diperkirakan netter Indonesia bakal mencapai 112 juta orang yang dimana mayoritas pengguna adalah netter dengan perangkat ponsel dan koneksi broadband mobile terjangkau (https://kominfo.go.id).sehingga dengan beragamnya system operasi yang diadopsi oleh vendor perangkat menjadikan media website menjadi sebuah media yang bersifat multi-platform yang tidak mengenal adanya perbedaan system operasi yang diadopsi oleg berbagai macam vendor perangkat mobile. 


\section{TINJAUAN PUSTAKA}

Wibowo,S.A.,Rokhman,M,M.,Pranoto,Y,A. dalam penelitianya pada tahun 2017 menyatakan bahwa Pencarian suatu tempat dengan menggunakan peta konvensional dirasakan masih menyusahkan bagi sebagian orang. Hal ini terkait dengan ukuran peta yang relatif besar sehingga kurang efektif dalam penggunaannya. Isu pemerataan dan peningkatan mutu pelayanan tidak terlepas dari peningkatan jangkauan dan perluasan pelayanan kesehatan, termasuk pembangunan kesehatan di daerah-daerah pinggiran kota besar salah satunya yaitu di kabupaten Malang. Penyelenggaraan upaya pelayanan kesehatan di daerah seringkali mengalami hambatan karena sulitnya medan. Tidak ada atau kurangnya sarana transportasi, komunikasi, serta minimnya informasi letak geografis,sehingga permasalahan tersebut menjadi isu penting yang terjadi di masyrakat yang menjadikan kurang popuernya akses kesehatan di PUSKESMAS yang seharusnya menjadi Sebagai sarana pelayanan kesehatan terdepan terutama di wilayah kabupaten malang.

Oleh karena itu, diperlukan sebuah Sistem Informasi Geografis (SIG) untuk memetakan pusat kesehatan masyarakat khususnya di wilayah kabupaten malang

\subsection{Web Sistem Informasi Geografis (Web-GIS)}

Web-GIS merupakan suatu aplikasi berbasis SIG yang terdiri dari beberapa komponen yang saling terkait. Web-GIS merupakan gabungan antara design grafis pemetaan, peta digital dengan analisa geografis, pemrograman komputer, dan sebuah database yang saling terhubung menjadi satu bagian web design dan web pemetaan.

Pengembangan aplikasi SIG kedepannya mengarah kepada aplikasi berbasis Web yang dikenal dengan Web-GIS. Hal ini disebabkan karena pengembangan aplikasi di lingkungan jaringan telah menunjukan potensi yang besar dalam kaitannya dengan geoinformasi. Sebagai contoh adalah adanya peta online sebuah kota dimana pengguna dapat dengan mudah mencari lokasi yang diinginkan secara online melalui jaringan intranet/internet tanpa mengenal batas geografi penggunanya. Secara umum Sistem Informasi Geografis dikembangkan berdasarkan pada prinsip input/masukan data, menegemen, analisis dan representasi data. Di lingkungan web prinsip-prinsip tersebut di gambarkan dan di implementasikan seperti pada Tabel .1:
Tabel 1. Prinsip - prinsip Pengembangan GIS

\begin{tabular}{|l|l|}
\hline \multicolumn{1}{|c|}{ GIS Prinsip } & \multicolumn{1}{c|}{ Pengembangan Web } \\
\hline Data Input & Client \\
\hline Management Data & $\begin{array}{l}\text { DBMS dengan } \\
\text { Komponen spasial }\end{array}$ \\
\hline Analisis Data & GIS Library di server \\
\hline Representasi Data & Client server \\
\hline
\end{tabular}

\section{METODE PENELITIAN}

Perancangan aplikasi ini meliputi kebutuhan fungsional sebagai berikut:

1. Aplikasi ini mutlak menggunakan koneksi media internet.

2. Aplikasi menggunakan website sebagai media untuk pengoperasiannya.

3. Memiliki dua hak akses yaitu user dan admin.

4. Dirancang dengan menggunakan Bahasa pemrograman php,

5. Menggunakan Database yang disupport Mysql

6. Untuk hasil pengujian dilakukan menggunakan brwser Mozilla firefox,internet explorer,dan opera.

7. Cakupan wilayah meliputi wilayah kabupaten Malang

Untuk perencanaan system struktur menu admin dan user dapat ditunjukkan dlam gambar 1 dan 2

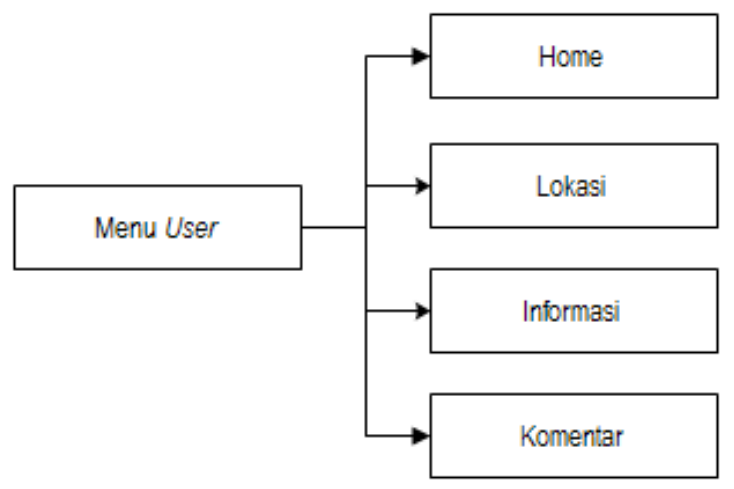

Gambar 1. Struktur Menu User 


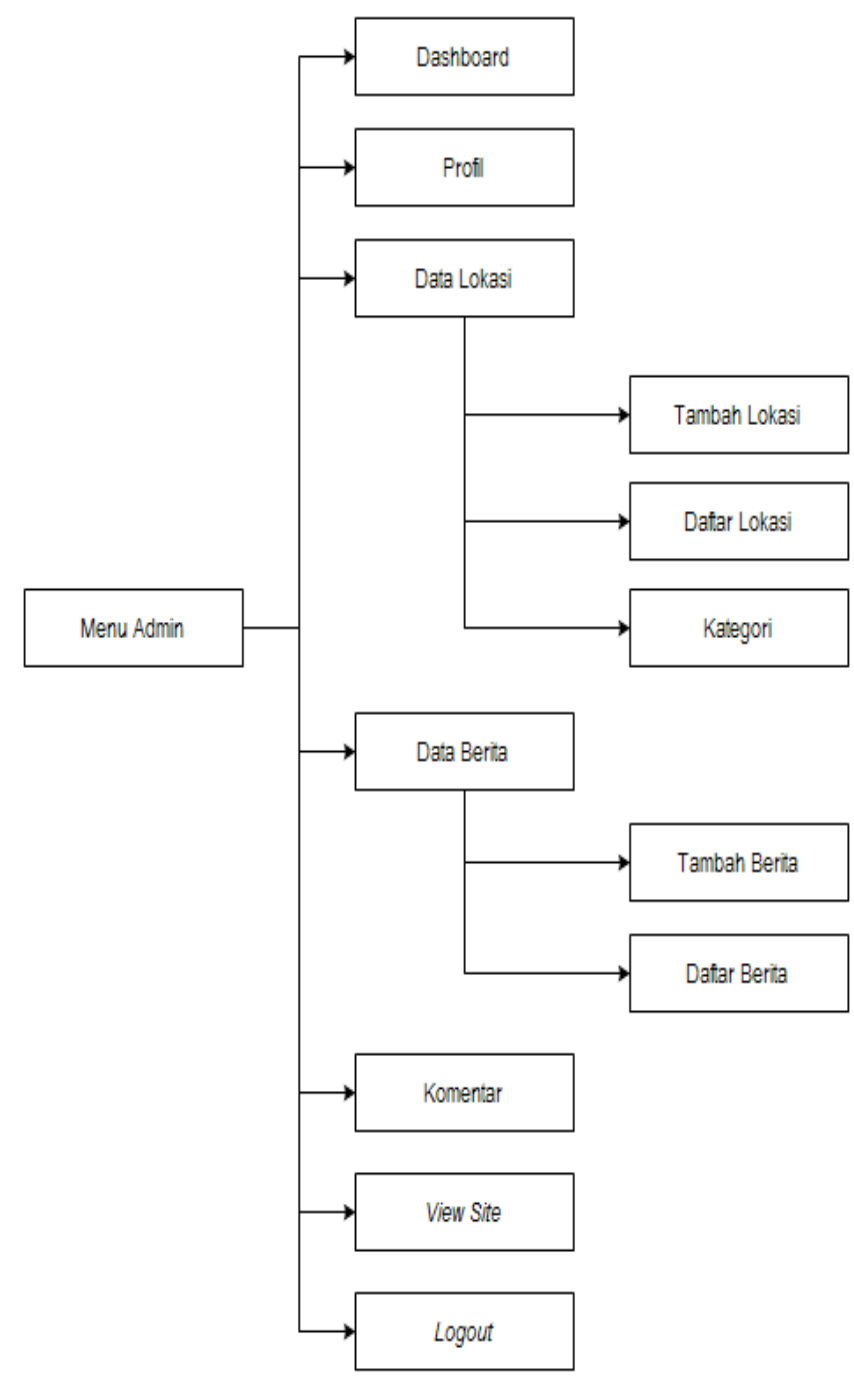

Gambar 2. Struktur Menu Admin

\section{HASIL DAN PEMBAHASAN}

\subsection{Hasil}

Hasil dari program untuk tampilan pada halaman utama (depan) dapat ditunjukkan dalam Gambar 3

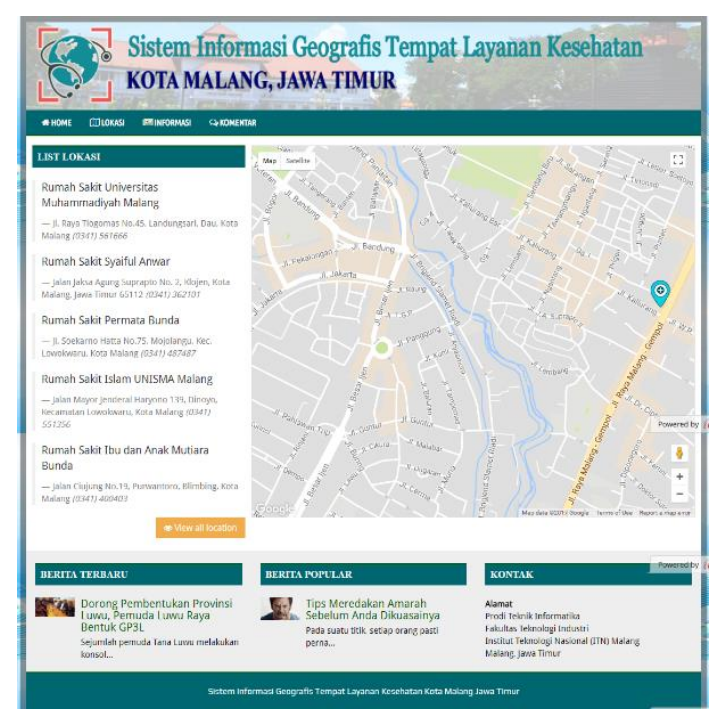

Gambar 3. Halaman Utama
Hasil dari program untuk tampilan pada halaman pemetaan data fasilitas kesehatan utama dapat ditunjukkan dalam gambar 4 .

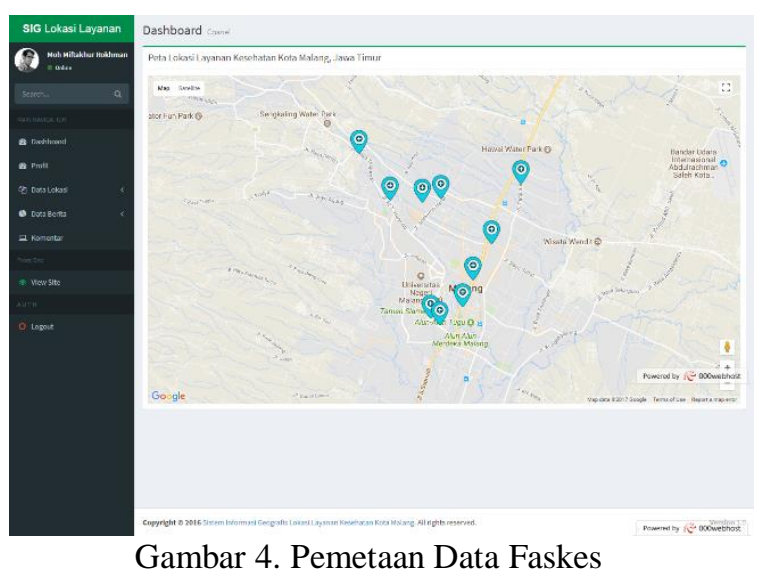

Hasil dari program untuk tampilan pada halaman input data faskes dapat ditunjukkan dalam Gambar 5

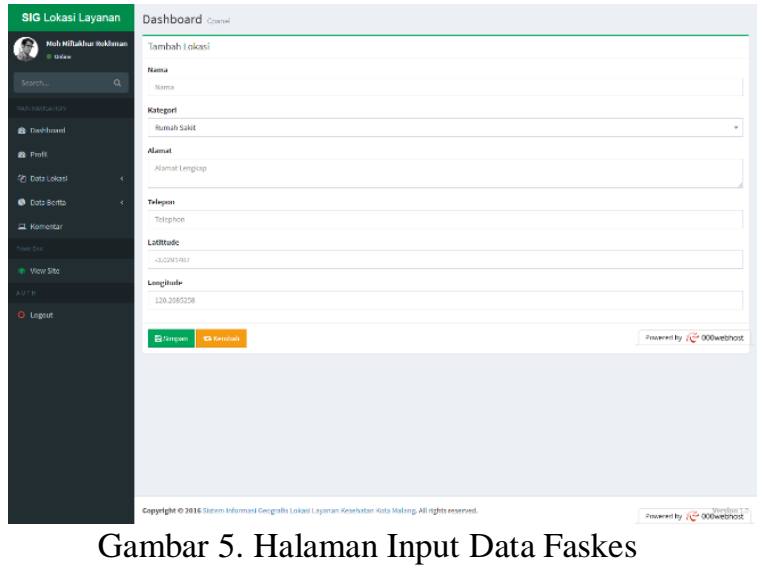

Hasil dari program untuk tampilan pada halaman data hasil input fasilitas kesehatan dapat ditunjukkan dalam Gambar 6

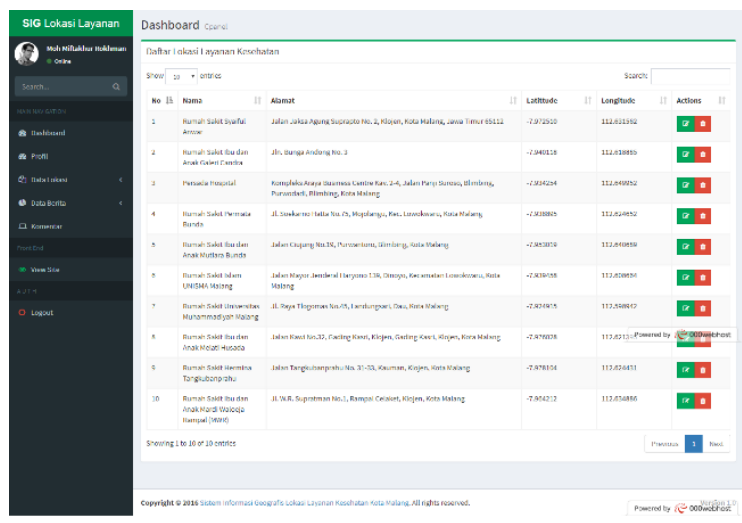

Gambar 6. Halaman Data Hasil Input Faskes

Hasil dari program untuk tampilan pada halaman input jenis fasilitas kesehatan dapat ditunjukkan dalam gambar 7 


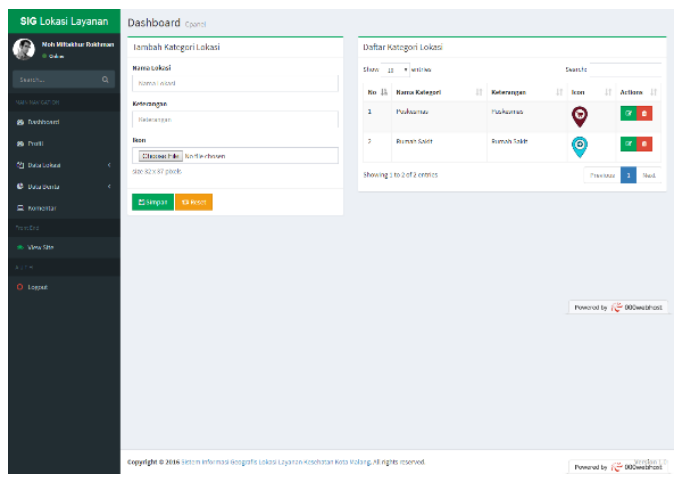

Gambar 7. Halaman Input Jenis Faskes

Hasil dari program untuk tampilan pada halaman input informasi atau berita dapat ditunjukkan dalam gambar 8 .

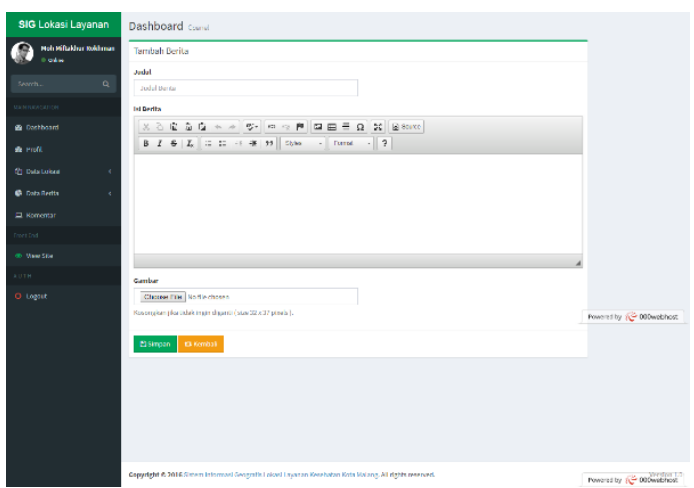

Gambar 8. Halaman Input Informasi atau Berita

\subsection{Pengujian}

Pengujian fungsional dilakukan untuk mengetahui apakah fungsi sudah sesuai dengan kebutuhan atau belum. Pengujian ini juga dilakukan untuk mengatasi error dan menguji validation yang seringkali dilakukan tidak sesuai dengan ketentuan penggunaan aplikasi. Tabel 2 adalah pengujian fungsi menggunakan desktop computer sebagau bahan uji

Tabel 2 Pengujian fungsi menggunakan desktop computer

\begin{tabular}{|c|l|c|c|c|}
\hline \multirow{4}{*}{$\begin{array}{c}\text { Hak } \\
\text { akses }\end{array}$} & \multirow{2}{*}{ Fungsional } & $\begin{array}{c}\text { Mozilla } \\
\text { firefox }\end{array}$ & $\begin{array}{c}\text { Internet } \\
\text { explorer }\end{array}$ & Opera \\
\hline \multirow{4}{*}{ User } & Menu Utama & $\sqrt{ }$ & $\sqrt{ }$ & $\sqrt{ }$ \\
\cline { 2 - 5 } & Home & $\sqrt{ }$ & $\sqrt{ }$ & $\sqrt{ }$ \\
\cline { 2 - 5 } & Lokasi & $\sqrt{ }$ & $\sqrt{ }$ & $\sqrt{ }$ \\
\cline { 2 - 5 } & Informasi & $\sqrt{ }$ & $\sqrt{ }$ & $\sqrt{ }$ \\
\hline \multirow{4}{*}{ Admin } & Komentar & $\sqrt{ }$ & $\sqrt{ }$ & $\sqrt{ }$ \\
\cline { 2 - 5 } & Dashboard & $\sqrt{ }$ & $\sqrt{ }$ & $\sqrt{ }$ \\
\cline { 2 - 5 } & profil & $\sqrt{ }$ & $\sqrt{ }$ & $\sqrt{ }$ \\
\hline \multirow{5}{*}{ Admin } & Data lokasi & $\sqrt{ }$ & $\sqrt{ }$ & $\sqrt{ }$ \\
\cline { 2 - 5 } & Kategori & $\sqrt{ }$ & $\sqrt{ }$ & $\sqrt{ }$ \\
\cline { 2 - 5 } & Data berita & $\sqrt{ }$ & $\sqrt{ }$ & $\sqrt{ }$ \\
\cline { 2 - 5 } & Tambah berita & $\sqrt{ }$ & $\sqrt{ }$ & $\sqrt{ }$ \\
\cline { 2 - 5 } & Daftar berita & $\sqrt{ }$ & $\sqrt{ }$ & $\sqrt{ }$ \\
\cline { 2 - 5 } & Komentar & $\sqrt{ }$ & $\sqrt{ }$ & $\sqrt{ }$ \\
\cline { 2 - 5 } & View site & $\sqrt{ }$ & $\sqrt{ }$ & $\sqrt{ }$ \\
\cline { 2 - 5 } & Log out & $\sqrt{ }$ & $\sqrt{ }$ \\
\hline
\end{tabular}

Keterangan: $\sqrt{ }=$ berhasil/sesuai

$$
\mathrm{x} \text { = gagal/tidak sesuai }
$$

Fungsional 100\% sudah berjalan sesuai dengan kebutuhan aplikasi yang dilakukan oleh browser Mozilla Firefox, Opera, dan Internet Explorer..

Tabel 3 Pengujian fungsi menggunakan media browser pada perangkat mobile

\begin{tabular}{|c|l|c|c|c|}
\hline \multirow{4}{*}{$\begin{array}{c}\text { Hak } \\
\text { akses }\end{array}$} & \multirow{2}{*}{ Fungsional } & \multicolumn{1}{|c|}{$\begin{array}{c}\text { Uc } \\
\text { browser }\end{array}$} & $\begin{array}{c}\text { Google } \\
\text { chrome }\end{array}$ & Opera \\
\hline \multirow{4}{*}{ User } & Menu Utama & $\sqrt{ }$ & $\sqrt{ }$ & $\sqrt{ }$ \\
\cline { 3 - 6 } & Home & $\sqrt{ }$ & $\sqrt{ }$ & $\sqrt{ }$ \\
\cline { 2 - 5 } & Lokasi & $\sqrt{ }$ & $\sqrt{ }$ & $\sqrt{ }$ \\
\cline { 2 - 5 } & Informasi & $\sqrt{ }$ & $\sqrt{ }$ & $\sqrt{ }$ \\
\hline \multirow{4}{*}{ Admin } & Komentar & $\sqrt{ }$ & $\sqrt{ }$ & $\sqrt{ }$ \\
\cline { 2 - 5 } & Dashboard & $\sqrt{ }$ & $\sqrt{ }$ & $\sqrt{ }$ \\
\cline { 2 - 5 } & profil & $\sqrt{ }$ & $\sqrt{ }$ & $\sqrt{ }$ \\
\hline \multirow{5}{*}{ Admin } & Data lokasi & $\sqrt{ }$ & $\sqrt{ }$ & $\sqrt{ }$ \\
\cline { 2 - 5 } & Kategori & $\sqrt{ }$ & $\sqrt{ }$ & $\sqrt{ }$ \\
\cline { 2 - 5 } & Data berita & $\sqrt{ }$ & $\sqrt{ }$ & $\sqrt{ }$ \\
\cline { 2 - 5 } & Tambah berita & $\sqrt{ }$ & $\sqrt{ }$ & $\sqrt{ }$ \\
\cline { 2 - 5 } & Daftar berita & $\sqrt{ }$ & $\sqrt{ }$ & $\sqrt{ }$ \\
\cline { 2 - 5 } & Komentar & $\sqrt{ }$ & $\sqrt{ }$ & $\sqrt{ }$ \\
\cline { 2 - 5 } & View site & $\sqrt{ }$ & $\sqrt{ }$ & \\
\cline { 2 - 5 } & Log out & $\sqrt{ }$ & $\sqrt{ }$ & $\sqrt{ }$ \\
\hline
\end{tabular}

Keterangan: $\sqrt{ }=$ berhasil/sesuai

$\mathrm{x}=$ gagal/tidak sesuai

Fungsional $100 \%$ sudah berjalan sesuai dengan kebutuhan aplikasi yang dilakukan oleh browser google chrome,uc browser,opera

\subsection{Pengujian User}

Pengujian user dilakukan terhadap 24 responden yang terdiri dari masyarakat umum dan tenaga kesehatan yang nantinya akan sering mengakses aplikasi ini. Tabel 4 adalah hasil pengujian terhadap $u$ ser.

Tabel 4. Pengujian terhadap user

\begin{tabular}{|c|l|c|c|c|}
\hline \multirow{2}{*}{ No } & \multicolumn{2}{|c|}{ Pertanyaan } & \multicolumn{3}{|c|}{ Penilaian } \\
\cline { 3 - 5 } & & B & C & K \\
\hline 1 & Ergonomi desain aplikasi & 15 & 7 & 2 \\
\hline 2 & Handling penggunaan aplikasi & 16 & 4 & 4 \\
\hline 3 & Fitur informasi dan lokasi & 14 & 8 & 2 \\
\hline 4 & Pemanfaatan fitur komentar & 10 & 10 & 4 \\
\hline \multirow{2}{*}{5} & $\begin{array}{l}\text { Apakah aplikasi ini dapat } \\
\text { membantu masyarakat dalam } \\
\text { mencari lokasi layanan } \\
\text { kesehatan yang terdekat }\end{array}$ & 15 & 9 & - \\
\hline
\end{tabular}

Keterangan: $\mathrm{B}=$ Baik; $\mathrm{C}=$ Cukup; $\mathrm{K}=$ Kurang

Hasil pengujian user menunjukkan bahwa :

1. Pengguna menilai ergonomi desain aplikasi sudah baik :

$15 / 24 \times / 100 \%=62.5 \%$

2. Pengguna menilai Handling penggunaan aplikasi $16 / 24 \times 100 \%=66 \%$

3. Pengguna menilai informasi dan lokasi sudah memberikan manfaat : $14 / 24 \times 100=58 \%$ 
4. Pengguna menilai pemanfaatan fitur komentar sudah dapat digunakan beinteraksi dengan pengembang $10 / 24 \times 100 \%=41 \%$

Penilaian untuk kuisioner ini cukup rendah dikarenakan interaksi user tidak di respon secara realtime oleh pengelola website

5. Pengguna menilai aplikasi ini bermanfaat. $15 / 24 \times 100 \%=62,5 \%$

Dari hasil pengujian sistem didapatkan hasil untuk menu yang efektif membantu kinerja pengguna khususnya dari tenaga medis dengan membandingkan dua data yang terkait dengan pencarian data, data pertama menggunakan simulasi pencarian konvensional dengan mencari data di buku laporan dan dokumen puskesmas dan data kedua mengunakan pencarian data dengan media aplikasi pada website yang telah dibuat.seperti ditunjukkam dalam Tabel 5

Tabel .5 Pengujian efektifitas produk menggunakan media desktop browser

\begin{tabular}{|l|c|c|c|}
\hline Jenis implementasi & $\begin{array}{c}\text { Sistem } \\
\text { lama }\end{array}$ & web & efektifitas \\
\hline Pencarian lokasi & 12 menit & 2 menit & $83 \%$ \\
\hline $\begin{array}{l}\text { Pencarian informasi } \\
\text { yang dimiliki oleh } \\
\text { tempat layanan } \\
\text { kesehatan yang di tuju }\end{array}$ & 20 menit & 2 menit & $83 \%$ \\
\hline $\begin{array}{l}\text { Pencarian rute } \\
\text { terdekat untuk } \\
\text { mencapai lokasi } \\
\text { fasilitas kesehatan } \\
\text { yang diinginkan. }\end{array}$ & 30 menit & 3 menit & $90 \% \%$ \\
\hline \multicolumn{3}{|c|}{ Rata-rata efektifitas produk } & $87,7 \%$ \\
\hline
\end{tabular}

Dari hasil pengujian untuk efektifitas produk didapatkan hasil rata-rata efisiensi watu sebesar 27,885\% dimana visualisasi hasil pengujian dilihatkan pada gambar 9

Tabel .6 Pengujian efektifitas produk menggunakan media mobile browser

\begin{tabular}{|c|c|c|c|}
\hline Jenis implementasi & $\begin{array}{c}\text { Sistem } \\
\text { lama }\end{array}$ & $\begin{array}{c}\text { Aplikasi } \\
\text { web }\end{array}$ & $\begin{array}{l}\text { Prosentase } \\
\text { efektifitas }\end{array}$ \\
\hline Pencarian lokasi & $\begin{array}{c}12 \\
\text { menit }\end{array}$ & 5 menit & $58 \%$ \\
\hline $\begin{array}{l}\text { Pencarian informasi } \\
\text { yang dimiliki oleh } \\
\text { tempat layanan } \\
\text { kesehatan yang di tuju }\end{array}$ & $\begin{array}{c}20 \\
\text { menit }\end{array}$ & 3 menit & $85 \%$ \\
\hline $\begin{array}{lr}\text { Pencarian } & \text { rute } \\
\text { terdekat } & \text { untuk } \\
\text { mencapai } & \text { lokasi } \\
\text { fasilitas } & \text { kesehatan } \\
\text { yang diinginkan. }\end{array}$ & $\begin{array}{c}30 \\
\text { menit }\end{array}$ & 5 menit & $53 \%$ \\
\hline \multicolumn{3}{|c|}{ Rata - rata efektifitas produk } & $75 \%$ \\
\hline
\end{tabular}

Dari hasil pengujian efisiensi waktu terlihat bahwa untuk penggunaan aplikasi desktop browser memiliki efisiensi waktu yang dapat dihemat rata-rata sebesar 87,7
$\%$ sedangkan untuk penggunaan aplikasi mobile browser memiliki efisiensi waktu yang dapat dihemat rata-rata sebesar $75 \%$. Hal tersebut dipengaruhi karena dengan menggunakan media mobile yang menggunakan ukuran display jauh lebih kecil turut mempengaruhi performa usability pengguna dimana dalam hal ini sema device yang digunakan sebagai bahan uji menggunakan touchscreen media input sehingga sedikit merepotkan pengguna ketika harus memilih menu dalam bentuk text.

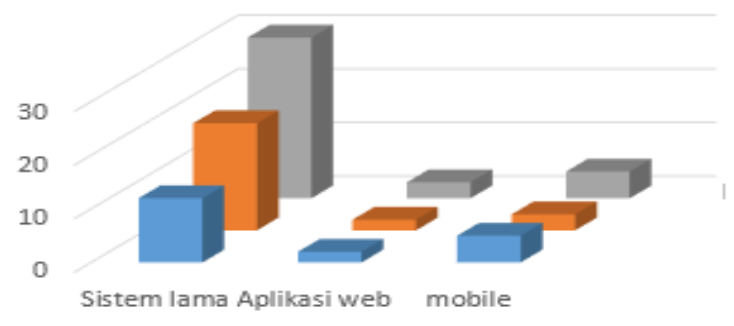

- Pencarian lokasi

- Pencarian informasi yang dimiliki oleh tempat layanan kesehatan yang di tuju

a Pencarian rute terdekat untuk mencapai lokasi fasilitas kesehatan yang diinginkan,

Gambar 9. Table efisiensi efiktifitas waktu

\section{KESIMPULAN DAN SARAN}

\subsection{Kesimpulan}

1. Pada pengujian fungsional, fungsi $100 \%$ sudah sesuai dengan kebutuhan aplikasi.

2. Pada pengujian fungsional penulis menyimpulkan bahwa $100 \%$ fungsi telah berjalan di browser desktop yang telah direncanakan

3. Pada pengujian fungsional penulis menyimpulkan bahwa $100 \%$ fungsi telah berjalan di browser mobile yang telah direncanakan

4. Hasil pengujian user menunjukkan bahwa $62,5 \%$ pengguna menilai tampilan aplikasi sudah baik, $66 \%$ pengguna menilai aplikasi mudah digunakan, 58\% pengguna menilai informasi dan lokasi telah memberikan manfaat dan $75 \%$ pengguna menilai aplikasi ini bermanfaat.

5. Dari hasil pengujian efisiensi waktu terlihat bahwa untuk penggunaan aplikasi desktop browser memiliki efisiensi waktu yang dapat dihemat rata-rata sebesar $87,7 \%$

6. sedangkan untuk penggunaan aplikasi mobile browser memiliki efisiensi waktu yang dapat dihemat rata-rata sebesar $75 \%$.

7. Perbedaan hasil pengujian efisiensi waktu dipengaruhi karena dengan menggunakan media mobile yang menggunakan ukuran display jauh lebih kecil turut mempengaruhi performa usability pengguna dimana dalam hal ini sema device yang digunakan sebagai bahan uji menggunakan touchscreen media input sehingga sedikit merepotkan pengguna ketika harus memilih menu dalam bentuk text. 


\subsection{Saran}

1. Diharapkan Pada Pengembangan Berikutnya Mencakup Wilayah Malang Kota Yang Lebih Padat Penduduk

2. Pada Penelitian Berikutnya Dapat Diberikan Fitur Location Based Service Untuk Memudahkan Pencarian Lokasi

3. Dapat Dikembangkan Meggunakan Aplikasi Mobile.

\section{DAFTAR PUSTAKA}

[1]. Adri, M. and Sriwahyuni, T., 2016. Sistem Informasi Geografis (Sig) Fasilitas Kesehatan Di Kabupaten Bungo Berbasis Mobile. Jurnal Vokasional Teknik Elektronika \& Informatika, 4.

[2]. Budiyanto Eko. 2002. Sistem Informasi Geografis Menggunakan ARC View GIS. Yogyakarta : Andi OFFSET

[3]. Indonesia, M.K.R., 2014. Peraturan Menteri Kesehatan Republik Indonesia Nomor 30 Tahun 2014 Tentang Standar Pelayanan Kefarmasian Di Puskesmas.

[4]. Informasi Geografis Berbasis Dekstop dan Web. Yogyakarta : Gava Media

[5]. Kadir, A. 2001. Dasar Pemrograman Web Dinamis Menggunakan PHP. Yogyakarta: ANDI

[6]. Makiolor, A.A., 2017. Rancang Bangun Pencarian Rumah Sakit, Puskesmas dan Dokter Praktek Terdekat di Wilayah Manado Berbasis Android. Jurnal Teknik Informatika Universitas Sam Ratulangi, 10.

[7]. PHP Manual. 2007 the PHP Documentation Group
[8]. Rahardjo, D. and Warkim, W., 2015. Prototipe Sistem Informasi Geografis Fasilitas Kesehatan di Kota Cirebon Berbasis Web. Jurnal Teknik Informatika dan Sistem Informasi, 1(3).

[9]. Riyanto \& Putra, Prinali Eka. 2009. Pengembangan Aplikasi Sistem

[10]. Saputra, A.B., Agustina, M. and Agustini, E.P., Pengembangan Sistem Informasi Geografis Fasilitas Kesehatan Kemenkes Berbasis Arcgis (Studi Kasus Kota Palembang).

[11]. Suryana, T., 2014. BPJS Kesehatan dan Daftar Fasilitas Kesehatan BPJS. BPJS Kesehatan dan Daftar Fasilitas Kesehatan BPJS.

[12]. Wibowo,S.A., Rokhman,M,M.,Pranoto,Y,A.

[13]. 2017.Aplikasi Pemetaan Berbasis Website Untuk Pusat Kesehatan Masyarakat Di Wilayah Kabupaten Malang , Jurnal Industri Inovatif, Vol.7 No.2.2017

[14]. Yustisia, T.P., 2014. Panduan Resmi Memperoleh Jaminan Kesehatan dari BPJS. VisiMedia.

[15]. Annonymous, https://Siknasonline.depkes.go.id/ , diakses pada tanggal 4 Pebruari 2017

[16]. Annonymous,https://en.wikipedia.org/wiki/Pu skesmas diakses pada tanggal 5 juli 2017

[17]. Annonymous, http://dinkes.malangkab.go.id/ diakses pada tanggal 5 juli 2017

[18]. Annonymous ,https://id.wikipedia.org/ wiki/ Kabupaten_Malang diakses pada tanggal 5 juli

[19]. Annonymous, https://kominfo.go.id/content/detail/4286/peng guna-internet-indonesia-nomor-enamdunia/0/sorotan_media 